Accepted versión of: Dočkalova, K. et al. "Brown and brook trout populations in the Tatra Mountain lakes (Slovakia, Poland) and contamination by long-range transported pollutants" in Biologia (Published by De Gruyter Open ) vol. 70, issue 4 (April 2015), p. 516-519. The final versión is available at DOI 10.1515/biolog-2015-0052

\title{
Brown and brook trout populations in the Tatra Mountain lakes (Slovakia, Poland) and contamination by long-range transported pollutants
}

\author{
Kateřina Dočkalováa*, Jana Holubcováa, Montse Bacardit ${ }^{\mathrm{b}}$, Mireia Bartrons ${ }^{\mathrm{c}}$, Lluís Camarero ${ }^{\mathrm{b}}$, Eva \\ Gallego $^{d}$, Joan Grimalt ${ }^{\mathrm{d}}$, David Hardekopf ${ }^{\mathrm{a}}$, Zuzana Hořickáa ${ }^{\mathrm{a}}$ Bjørn Olav Rosseland ${ }^{\mathrm{e}}$, Jolana Tátosováa \\ Evžen Stuchlík ${ }^{\mathrm{a}}$ \\ ${ }^{a}$ Institute for Environmental Studies, Charles University in Prague, Czech Republic, Benátská 2, 12801 Prague, \\ Czech Republic; email: katerina.kolarikova@ natur.cuni.cz, \\ ${ }^{\mathrm{b}}$ Limnological Observatory of the Pyrenees (LOOP), Centre for Advanced Studies of Blanes (CEAB-CSIC), \\ Spain \\ ${ }^{c}$ CREAF, Cerdanyola del Vallès, 08193 Barcelona, Catalonia, Spain \\ ${ }^{\mathrm{d}}$ Department of Environmental Chemistry, Institute of Environmental Assessment and Water Research (IDÆA- \\ CSIC) in Barcelona, Spain \\ ${ }^{\mathrm{e}}$ Department of Ecology and Natural Resource Management, Norwegian University of Life Sciences, Norway \\ *Corresponding author
}

\section{Abstract}

Fish living in the extreme conditions of the Tatra Mountain lakes were evaluated from a biological point of view as well as an important biomarker of long-range transported pollutants. In Vel'ké Hincovo pleso and in Morskie Oko, specimens of brown trout (Salmo trutta) of extraordinarily advance age were found (ages of 18+ and 17+ years, respectively). The capture of a 17+ year-old brown trout in Morskie Oko (2400g, 540mm) indicated the presence of the so-called ferox life strategy. The growth of brook trout (Salvelinus fontinalis) was faster than the growth of brown trout in the younger year classes, and while the growth of brook trout stopped after the age of $5+$, the growth of brown trout continued.

Concentrations of long-range transported pollutants (HCHs, HCB, DDTs, PCBs, PBDEs and trace metals) in the Tatra Mountain fish were mostly associated with fish age, body weight and length, type of fish tissue, and lake altitude.Persistent organic pollutants (POPs) in fish muscle were dominated by PCB 138, 153, 180, and p,p'DDE. Conversely, PBDEs concentrations ranged at substantially lower levels compared to other POPs. Altitude correlated significantly with concentrations of a-HCH, HCB, p,p'-DDT, p, p'-DDE, and with PCB 28 and 52. The highest contents of trace metals were found in kidney and liver samples, with higher concentrations in Vel'ké Hincovo pleso than in Morskie Oko. The overall highest trace metal concentration levels were found for $\mathrm{Fe}, \mathrm{Cu}$, and $\mathrm{Zn}$. In comparison with other European mountain lakes, the Tatra Mountain lakes are among the more contaminated.

Key words: fish growth, Salmo trutta, Salvelinus fontinalis, ferox, POPs, trace metals, mountain lakes, Tatra Mountains, long-range transport
Abbreviations:
HCB hexachlorobenzene;
HCHs
hexachlorocyclohexanes;
p,p'-DDT dichlorodiphenyltrichloroethane, p,p'-DDE dichlorodiphenyldichloroethylen, PBDEs polybrominated difenylethers; PCBs polychlorobiphenyls; POPs persistent organic pollutants; TMs trace metals and metalloids 


\section{Introduction}

Long-range transport of POPs has become one of the main environmental problems in the last decades (Fernandez \& Grimalt, 2003). The long distance aspect of their transport is determined by their physicalchemical properties (high stability, semivolatility, and hydrophobicity). Concentrations of POPs in remote ecosystems are elevated due to the Global Distillation Effect, which magnifies their movements from warm regions to cold regions where they can be trapped (Wania \& Mackay 1995, Fernandez \& Grimalt 2003).

Despite the remoteness of high mountain lakes, a number of studies in European (Vives et al. 2004, Fernandez et al. 2005, Gallego et al. 2007, van Drooge et al. 2013), Asian (Yang et al. 2010), and North American (Kidd et al. 1998, Ikonomou et al. 2002, Demers et al. 2007) mountain lakes have detected long-range transported pollutants such as PAHs, PBDEs, OCs, and TMs, both in sediment and in biota. Therefore, European high mountain lake ecosystems are sensitive environmental indicators for determining changes in air quality and the long-range atmospheric transport of pollutants (van Drooge et al. 2013). Due to their lipophilic character and resistance to degradation, POPs tend to accumulate in fat tissues (de Voogt \& Brinkman 1989). Because of their position at the top of the aquatic food chain and due to the process of biomagnification, fish are the most suitable biomarkers for monitoring global air pollution state in high mountain lakes.

Fish tissues were analyzed for HCHs, HCB, p,p'-DDT, p,p'-DDE, PCBs, PBDEs, and TMs in five lakes of the Tatra Mountains along an altitudinal gradient (1395-1946 m a.s.1.). Pollutant concentrations were analyzed in relation to both environmental and biological parameters. In addition, the data on fish parameters provide original and unique information about somatic fish growth and the extreme environmental condition of these high mountain lakes.

\section{Methods}

Study sites and sample collection

The Tatra Mountain lakes are of glacial origin and oligotrophic; details of their water chemistry can be found in Kopáček et al. (2006). This study was performed in five selected lakes (from a total 221 lakes, predominantly fishless) in the Tatra Mountains, both on the Slovak side: Vel'ké Hincovo pleso (VH) and Popradské pleso (PP), and the Polish side: Morskie Oko (MO), Zielony Staw Gąsienicowy (ZS), and Czarny Staw Polski (CS) (Fig. 1) to cover an altitudinal gradient between 1395 and $1946 \mathrm{~m}$ a.s.l. Lake characteristics are given in Table 1. All lakes are located in national parks of the respective countries, so they are neither fished nor disturbed by any substantial human activity. The lakes are far from industrial activities and are not connected to anthropogenically affected inflows, only PP receives untreated sewage water from a hotel on the bank. Except for PP and MO with native Salmo trutta, the lakes were originally fishless but repeatedly stocked with Salvelinus fontinalis (ZS and $\mathrm{CS})$ and Salmo trutta (VH) during the last several centuries.

Fish sampling was carried out in 2001 (only in VH) and 2004 in accordance with EMERGE proceedings (Rosseland et al. 2001), and sampling for metal analysis was done separately in 2004 in MO and 2005 in VH. 
Fish were collected by fly fishing and spinning from the bank in several different spots around the perimeter of each lake. To avoid the consequences of stress, fish were immediately killed, measured (total length), weighed and dissected to determine sex, maturation stage (I-VII, Table 2) and level of stomach filling $(0-5,0=$ empty, 1 $=$ food remains only in the end of the intestine, $5=$ full). The conditioning factor $\mathrm{C}$ was calculated after Rosseland et al. (2007a) for each fish according to the equation:

$C=100000 *$ weight $(\mathrm{g}) /$ length $(\mathrm{mm})^{\wedge} 3$,

where $\mathrm{C}=1$ is a well-shaped fish.

Scales and otoliths were taken for determination of age. Samples for POPs and TMs were immediately frozen in liquid nitrogen or in a cooler with dry ice.

\section{Chemical analyses}

POPs (HCB, HCHs, DDTs, PBDEs, PCBs) were analyzed in fish muscles according to the method described by Berdie \& Grimalt (1998). Limits of quantification of POPs were calculated from actual samples as the mean of the noise signal plus 3 times the standard deviation $(\mathrm{n}=5)$. They were in the range of $9.2-13$ and $13-16 \mathrm{pg} \mathrm{g}^{-1}$ ww muscle for OCs (HCHs, HCB, DDTs, and PCBs) and PBDEs, respectively. Lipid content was determined gravimetrically using $20 \%$ of the extract prepared for POP analyses. For TM analyses, 50-100 mg dw of fish gill, kidney, liver, and muscle were extracted in $\mathrm{HNO}_{3}$ with $\mathrm{H}_{2} \mathrm{O}_{2}(2: 1)$ at $95^{\circ} \mathrm{C}$ in Teflon bottles for $16 \mathrm{~h}$. Diluted extracts were analyzed by ICP-OES with a Perkin Elmer Optima 3200RL for Fe and by ICP-MS with a Perkin Elmer ELAN 6000 for Al, As, Cd, Cu, Mn, Ni, Pb, Se, Ti, and $\mathrm{Zn}$. Limits of quantification of metals were determined to be: $5 \mu \mathrm{g} \mathrm{L}^{-1} \mathrm{Al}, 0.10 \mu \mathrm{g} \mathrm{L}^{-1} \mathrm{As}, 0.05 \mu \mathrm{g} \mathrm{L}^{-1} \mathrm{Cd}, 0.05 \mu \mathrm{g} \mathrm{L}^{-1} \mathrm{Cu}, 10 \mu \mathrm{g} \mathrm{L}^{-1} \mathrm{Fe}, 0.10 \mu \mathrm{g} \mathrm{L}^{-1} \mathrm{Mn} 0.20$ $\mu \mathrm{g} \mathrm{L}{ }^{-1} \mathrm{Ni}, 0.05 \mu \mathrm{g} \mathrm{L}^{-1} \mathrm{~Pb}, 1.0 \mu \mathrm{g} \mathrm{L}^{-1} \mathrm{Se}, 0.50 \mu \mathrm{g} \mathrm{L}^{-1} \mathrm{Ti}, 0.20 \mu \mathrm{g} \mathrm{L}^{-1} \mathrm{Zn}$.

\section{Analytical quality assurance}

Two extraction blanks were produced within each batch of sample extractions. Certified reference materials were extracted and analyzed together with samples: CRM 281, obtained from the Community Bureau of Reference; and ERM-CE278 obtained from the Institute for Reference Materials and Measurements. Analytical accuracy fell within the certified values. In addition to the internal controls with blanks and standards, the laboratories participate regularly in inter-comparison exercises organized as part of the UN-ECE International Cooperative Programme on the Assessment and Monitoring of Acidification of Rivers and Lakes (ICP-Waters) (Hovind 2005, 2006).

\section{Results}

\section{Fish characterization}

An overview of all sampled specimens and average fish parameters are shown in Table 3. There was no difference in ages between males and females (Mann-Whitney, $\mathrm{p}<0.05$ ). The ages of individual fish ranged between 3 and 17 years. The highest average age was in VH in both 2005 and 2001 (brown trout), though the largest fish in average were found in CS (brook trout) (Table 3). Overall, an exceptionally large fish was found in MO (brown trout, $540 \mathrm{~mm}, 2400 \mathrm{~g}, 17$ years). The growth rate of both fish species in the Tatra Mountain lakes 
was low. The oldest brown trout grew to $255 \mathrm{~mm}$ and $160 \mathrm{~g}$ on average. The oldest brook trout were $200 \mathrm{~mm}$ long and weighed $76 \mathrm{~g}$ on average; however, in CS younger fish groups were even larger on average (334 mm, $408 \mathrm{~g})$.

The length and weight of brown trout were much more variable (130-540 mm and 14-2,400 g) than for brook trout (155-380 mm and 38-580 g) (Figs. 2, 3). Brook trout had faster initial growth than brown trout, but their weight increment ceased after $5+$ years. The highest dependences of both weight and length on age were found for brown trout in MO in $2004(\mathrm{r}=0.97$ and $\mathrm{r}=0.97$, respectively) and in VH in $2001(\mathrm{r}=0.91$ and $\mathrm{r}=0.88$, respectively) (Fig. 2, 3).

Average condition factors were near to the ideal value (=1) for both brown trout and brook trout $(1.02 \pm 0.39$ and $1.01 \pm 0.21$, respectively) (Fig. 4A) and did not differ between species (Mann-Whitney, $\mathrm{p}<0.05$ ). However, the condition factor differed among the lakes (Kruskal-Wallis, $\mathrm{p}<0.05$ ), with the highest average values for brook trout in CS $(1.19 \pm 0.18)$ and for brown trout in VH $(1.04 \pm 0.06)$. Condition factor correlated negatively with the age of fish in all lakes, especially for brook trout; however, none of these correlations were significant $(p<0.05)$. Condition factors for all fish versus the age of fish had a bimodal shape (Fig. 5).

The degree of maturation was different among fish from particulate lakes. In general the value increased with altitude, but was again lower in VH, the highest lake in altitude (Fig. 4B). The age of fish sampled were, however, not comparable, since, for example, fish in CS were only of three age groups (4+ to 6+) whereas fish in $\mathrm{PP}$ and $\mathrm{MO}$ ranged from $3+$ to $10+$. The good condition of fish in CS is indicated by the fact that stomach filling was highest in this lake (Fig. 4C), and the value was significantly different from values in MO and ZS (KruskalWallis, $p<0.05$ ). Lipid contents were similar (total average 1.6\%) and did not differ among the lakes (KruskalWallis, $\mathrm{p}<0.05$ ), even when females were excluded from the comparison. Nevertheless, maximum lipid content values were lower in lakes with increasing altitude (Fig. 4D).

A brief inspection of fish stomachs during dissection revealed that fish fed largely on zooplankton, composed mainly of Cyclops abyssorum. Another important source of food was emerging pupae of chironomids, and at lower elevations littoral macrozoobenthos and terrestrial insects. Some of the larger fish were piscivorous.

\section{POP concentrations}

The highest overall POP concentration was measured for $\mathrm{p}, \mathrm{p}^{\prime}$-DDE in the largest specimen in MO $\left(1,274 \mu \mathrm{g} \mathrm{kg}^{-1}\right.$ ww) due to the advanced age of this fish (17 years) and its exceptional body size (2400 g, $540 \mathrm{~mm})$. Other concentrations of p, $\mathrm{p}^{\prime}$-DDE were much lower and ranged in concentrations 1-2 orders higher (up to $69 \mu \mathrm{g} \mathrm{kg}^{-1}$ ww) than concentrations of p, $\mathrm{p}^{\prime}$-DDT (up to $7 \mu \mathrm{kg}^{-1} \mathrm{ww}$ ) (Fig. 6, 7B). Variable concentrations were measured for PCBs 138, 153, and 180 (from 17 to $199 \mu \mathrm{g} \mathrm{kg}^{-1} \mathrm{ww}$ ). The relative composition of PCB congeners was dominated in all lakes by the congeners 138, 153, and 180 (Fig. 7C). Of all POP pollutants, the lowest concentrations were found for PBDEs (in $\mathrm{n} \mathrm{kg}^{-1} \mathrm{ww}$ ). The relative composition of PBDEs congeners was very similar among the lakes (Fig. 7D) and was dominated mainly by PBDEs 47 and 99. In contrast, the lowest percentages were for PBDEs 100, 153 and 154. Very low concentrations were found for HCHs (Fig. 6) with a similar relative distribution of both isomers among the lakes, where $\mathrm{g}-\mathrm{HCH}$ (average $2.1 \pm 2.0 \mu \mathrm{g} \mathrm{kg}^{-1} \mathrm{ww}$ ) 
ranged at about one order higher concentrations than a-HCH (average $0.2 \pm 0.1 \mu \mathrm{g} \mathrm{kg}^{-1} \mathrm{ww}$ ) (Fig. 7A). HCB exhibited a similar concentration range to that of a-HCH, with average concentrations of $0.3 \pm 0.2 \mu \mathrm{g} \mathrm{kg} \mathrm{g}^{-1} \mathrm{ww}$ (Fig. 6).

When comparing even-aged fish (groups of 5+ and 6+ specimens), all POP concentrations were statistically different among the lakes (Kruskal-Wallis, $\mathrm{p}<0.05$ ) with the exception of PCB 52. The most contaminated lakes were PP and VH, except for PBDEs with the highest concentrations in CS.

Fish age correlated in only very few cases with POP concentrations ( $<$ < 0.05) (Table 4). A higher number of correlations $(\mathrm{p}<0.05)$ were found between body weight and POP concentrations, and very similar correlations were found between length and POP concentrations (Table 4), although some of them were not statistically significant. The fish condition factor was significantly $(\mathrm{p}<0.05)$ positively correlated with pollutant concentrations in their bodies; however several correlations were even negative (Table 4). Most POP concentrations correlated with lipid content $(\mathrm{p}<0.05)$, but among the PBDEs only PBDE 99 was correlated (Table 4).

Again when comparing even-aged fish (groups of 5+ and 6+ specimens), concentrations of HCB $(r=0.47), p, p^{\prime}-$ DDT $(r=0.41), p, p^{\prime}-D D E(r=0.79)$, and PCB $28(\mathrm{r}=0.45)$ correlated with lake altitude $(\mathrm{p}<0.05)$. No significant (Mann-Whitney, $\mathrm{p}<0.05$ ) difference in concentrations between females and males was found. Altogether, several compounds significantly $(\mathrm{p}<0.05)$ positively correlated even with concentrations of some other compounds: $\mathrm{HCB}$ with g-HCH, p,p'-DDT, p,p'-DDE, and PCBs, p,p'-DDT with p,p'-DDE, PCBs with HCHs (with a-HCH mostly negatively), p,p'-DDT, and PCBs. PBDEs correlated only with other particular PBDEs.

\section{Trace metal concentrations}

TM concentrations measured in MO and VH differed among the different fish tissues (muscle, liver, kidney, and gills) (Kruskal-Wallis, p < 0.05) except for As. The highest concentrations were measured in the kidney and liver, except for Mn with highest concentrations in the gills (Table 5). On the contrary, the lowest concentrations were found in muscle. Overall, the highest concentration levels were found for Fe in kidney (1942 \pm 710 and 747 $\pm 249 \mathrm{mg} \mathrm{kg}^{-1} \mathrm{dw}$ ) and liver (1152 \pm 656 and $\left.464 \pm 171 \mathrm{mg} \mathrm{kg}^{-1} \mathrm{dw}\right)$ in VH and MO, respectively, followed by $\mathrm{Cu}$ in liver $\left(907 \pm 369\right.$ and $\left.457 \pm 302 \mathrm{mg} \mathrm{kg}^{-1} \mathrm{dw}\right)$ in $\mathrm{VH}$ and $\mathrm{MO}$, respectively, and $\mathrm{Zn}$ in concentrations comparable among different tissues but lower in muscle. The lowest concentrations were found for As, $\mathrm{Ni}$, and Ti as they ranged mostly $<1 \mathrm{mg} \mathrm{kg}^{-1} \mathrm{dw}$.

Generally, higher concentrations were found in $\mathrm{VH}$ compared to $\mathrm{MO}$ with the exception of $\mathrm{Zn}$, and these differences were statistically significant for $\mathrm{Al}, \mathrm{Cd}, \mathrm{Cu}, \mathrm{Pb}, \mathrm{Se}$, and Ti (Mann-Whitney, p<0.05).

Metal concentrations correlated with age, length, weight, and/or condition factor (Table 6). Both significant ( $\mathrm{p}<$ 0.05 ) and non-significant correlations of condition factor with concentrations were predominantly negative. Metal concentrations were mostly positively correlated with age and length, with the exception of negative correlations of As, Mn, and Ni. Among metals, Ti was best correlated with age, length, weight, and condition 
factor. Among the different fish tissues, most of the significant correlations were found for kidney followed by gills and muscle (Table 6).

\section{Discussion}

Fish inhabiting mountain lakes have to survive extreme environmental conditions, with low water temperature, long ice covered periods, and mostly low ionic conditions and low productivity in the aquatic habitat. The low water temperature is most probably the reason for the advanced age of several brown trout found in VH 2001 and in MO and one brook trout in ZS (9+). For example, water temperature in VH from October to June does not exceed $4^{\circ} \mathrm{C}$ in the ice free period (unpublished data). Advanced age is not exceptional in suchlike conditions as Ligaszewski (1997) found brown trout (9+) and brook trout (10+), Rosseland et al. (2007a) found brown trout (11+) and Rognerud et al. (2002) even found 26+ old Arctic charr (Salvelinus alpinus). From this comparison, it can be stated that in the Tatra lakes, fish can survive to similar advanced ages as in the High Arctic. Nevertheless, compared to previous studies in Polish and Slovak Tatras (Lysak 1996, Kirka 1997), and even compared to other European mountain lakes (Lysak 1996), growth in our study was slow. This slow growth could be explained by the lower productivity of our studied lakes affecting the amount of available food as well as intraspecific competition.

Brook trout differ significantly from brown trout in their somatic growth. Brook trout may be characterized by more intensive weight growth than brown trout during the first five years of life, whereas length growth continued throughout adulthood in both species. This is in contrast to the results of Lysak (1997) who reported that both weight and length growth was faster in brook trout than than in brown trout, but that brook trout stop their growth in older ages. It can be supposed that brown trout are able to continue to grow when switching to cannibalistic feeding, as was seen in the largest specimen in MO (540 mm, $2400 \mathrm{~g}, 17$ years) that had a small brown trout $(17 \mathrm{~cm})$ in its stomach. A similar finding was reported Rognerud et al. (2002) from Norway. Hammer (2000) considered cannibalism of Arctic char an important strategy for survival in Arctic lakes. The missing fish from age groups between 10 and 17 years in MO and the substantial increase in body parameters between these age groups could be considered in association with the ferox life strategy described in Scotland (Campbell 1979), Great Britain and Ireland (McKeown et al. 2010), and Norway (Jensen et al. 2012) that is characterized by a switch to predatory feeding, thus achieving rapid growth. This particular fish in MO is the first direct evidence of a ferox type population in the Tatra lakes.

Brook trout reached substantially higher proportions in CS than in ZS, similarly as reported by Lysak (1997). This faster growth could be explained by the presence of individuals migrating to CS from the lake Wielki Staw, with lower intraspecific competition or better food sources. Krno et al. (2006) considered CS one of the most diverse Tatra lakes thanks to the high number of macroinvertebrate species. The faster growth and higher individual biomass of brook trout in CS compared to all other studied lakes could also be the result of feeding resources: the more stressful winter period, accompanied by starvation of fish as a result of a lack of food, parasitism and chance illness, may depress the abundance of fish in these isolated lakes and result in a drop in intraspecific competition. Another explanation could be the size of available spawning sites. As we frequently found semi-resorbed eggs in the prespawning fish we assume that the energy saved due to the lack of a spawning ground could be used to prolong somatic growth, and in addition, the eggs retained in the body cavity of these 
"stand by" fish are completely resorbed later and used as a source of energy. We have little evidence about the importance of layed eggs as source of food, but we would expect this resource to be significant.

According to the condition factor both species were in good condition. The condition factor did not differ between both species, in contrast to Ligaszewski (1997) who found a higher condition factor for brook than for brown trout. The condition factor did not significantly correlated with age of fish, contrary to the findings of Kirka (1974) and Vives et al. (2004).

The degree of maturation stage could not be assessed in relation to lake altitude, as in some lakes spawning fish might have moved closer to spawning sites at the time of fishing and become less catchable, for example. The higher range of lipid contents in MO and PP could be explained by the possible influence of fish migrated upstream from the sites of much lower altitude coming in through the lake outflows.

Cyclops abyssorum was found to be a main food source for fish. Large bodied planktonic cladocerans such as Daphnia pulicaria, Daphnia longispina or Holopedium gibberum usually do not survive intensive fish predation and soon disappear after artificial stocking of lakes. Emerging pupae of chironomids are only a temporarily available food source. Littoral macroinvertebrates and terrestrial insects, deposited by currents over the surface of lakes during the ice-free period, are a substantial food source at rather lower elevations, as the littoral of these lakes is more expansive than that of alpine lakes, and forested catchments provide more organic matter than poor rocky catchments above timber line. Larger fish can switch to a cannibalistic feeding pattern, allowing them to continue somatic growth even after the age of 10, as seen in Fig. 2.

Overall, the highest concentrations of most POPs were found in the second lowest lake PP. Even though the Tatra Mountains are remote and of quite high elevation, the reason for the highest load of POPs in PP is questionable due to the lake location: among all studied lakes, PP is exposed to the south and is the closest lake to potential regional contamination sources, the influence of which cannot be excluded. In addition, a hotel on the banks of PP releases untreated sewage water to this lake, nevertheless, an unintended contamination from the parking place close to the hotel might be much more possible.

Relatively low concentrations of a-HCH compared to g-HCH found in fish muscle have also been seen in fish of sub-alpine lakes (Villa et al. 2011). Such an a-/g-HCH ratio might indicate a recent source of lindane (g-HCH); nevertheless, the explanation of Vives et al. (2005), who inferred that a-HCH dominates rather in water whereas it persists only negligibly in fish muscle, is very probable. Comparisons of $\mathrm{HCH}$ concentrations with other high mountain lakes showed that the Tatra lakes are more contaminated than lakes of the French Pyrenees (Blais et al. 2006), Italian Alps (Villa et al. 2011), and Tibetan Plateau (Yang et al. 2010), and are comparable with the Spanish Pyrenees (Vives et al. 2005) and other European mountain lakes (Grimalt et al. 2001, Vives et al. 2004a, Gallego et al. 2007). HCB concentrations found in Tatra lakes coud be assessed as comparable with other studied lakes (Vives et al. 2004a, Vives et al. 2005, Blais et al. 2006, Yang et al. 2010, Villa et al. 2011)

Higher $\mathrm{p}, \mathrm{p}^{\prime}$-DDE than $\mathrm{p}, \mathrm{p}^{\prime}-\mathrm{DDT}$ concentrations can be attributed to the transformation of accumulated $\mathrm{p}, \mathrm{p}^{\prime}-$ DDT in fish to the more stabile p, $p^{\prime}$-DDE (Vives et al. 2005). The ratio of p, $p^{\prime}-D D E / p, p^{\prime}-D D T$ was greater than 1, which indicates an older source of contamination (Villa et al. 2011). DDT concentrations found in this study, in the average range of $0.6-2.7 \mu \mathrm{g} \mathrm{kg}^{-1} \mathrm{ww}$, are among the highest observed in European high mountain lakes, along with Okoto lake (Rila mountains, Bulgaria) (Vives et al. 2004a). 
PCB concentrations were dominated by the more-chlorinated PCBs 138, 153, and 180, with the highest levels in PP. This is consistent with other studies from European mountain lakes (Grimalt et al. 2001, Vives et al. 2004a, Vives et al. 2005, Gallego et al. 2007b), as more-chlorinated and thus hydrophobic OCs accumulate rather in fish muscle whereas less-chlorinated PCBs prevail in the water (Vives et al. 2005). However, the concentration level of dominating PCBs is unexpectedly high and could be possibly connected with the contamination due to the hotel on the banks, as mentioned above. Overall, the Tatra lakes are among the highest contaminated lakes by PCBs in Europe (Vives et al. 2004, Villa et al. 2011).

Concentrations of PBDEs ranged on average from 22-334 $\mathrm{ng} \mathrm{kg}^{-1} \mathrm{ww}$. These concentrations were generally of the same order of magnitude as concentrations found in other European high-mountain lakes (Kierkegaard et al. 2004; Vives et al. 2004c, Gallego 2007); however, Gallego et al. (2007) found slightly higher concentrations of PBDEs in the Pyrenees than we found in the Tatras. On the other hand, the concentrations are very low when compared to sites in Greenland with concentrations of 1.8-8.2 $\mu \mathrm{g} \mathrm{kg}^{-1}$ ww (Christensen et al. 2002). It must also to be taken into account that PBDE concentrations in muscle were lower than those found in other freshwater fish from remote lakes located at lower altitudes (Evenset et al. 2005, de Wit et al. 2006) and in lakes with higher human impact (Luross et al. 2002, Zennegg et al. 2003). PBDEs 47 and 99 had the highest proportion among PBDEs, followed by PBDE 28. Similarly, Jansson et al. (1993) reported that PBDEs 47, 99, and 100 usually comprise $90 \%$ of the total amount in the aquatic environment, and PBDE 47 comprises $>60 \%$. Sjödin et al. (1998) found that one of the most commonly used commercial PBDE mixtures, Bromkal 70-5DE, contained 37\%, 35\%, 7\%, 4\% and 3\% of PBDE47, PBDE99, PBDE100, PBDE153 and PBDE154, respectively. Hence, the PBDE proportions in our study are similar to those found in the commercial mixture, with several differences, probably derived from the fate of these compounds in the environment (Manchester-Neesving et al. 2001). In particular the proportion of PBDE99 was lower and PBDEs 100, 153 and 154 were higher in our samples. Interestingly, Bartrons et al. (2011), who measured all PBDE congeners in rock biofilms of Vel'ké Hincovo, found PBDE 209, the only congener allowed for use in Europe, as the most dominant congener, substantially exceeding other PBDE concentrations (>50\% of total PBDE).

Even though the load of fish by POPs is related to the degree of contamination of the surrounding water and sediment, it is likely that the food web structure and biological factors (life span, growth) are important variables influencing POP concentrations (Kidd et al. 1998). Gallego et al. (2007) considered fish age one of the most important variable influencing less-volatile PCBs and p,p'-DDE, whereas the more-volatile PCBs 28 and 52 were not associated with age or fish size. Additionally, Rognerud et al. (2002) and Vives et al. (2005) reported fish age to be one of the most important variables explaining OC concentrations in high-mountain lake fish in Europe and Svalbard. The elimination rate of less-volatile PCBs from fish is very slow (Rognerud et al. 2002) as they are more lipophilic (Vives et al. 2005). In our study, however, fish age correlated in a very few cases with concentrations of a-HCH, HCB, p,p'-DDT, PCB 52, 101, and PBDE 153. Moreover, most of these correlations were negative. Negative correlations of PCBs in brook trout in CS could be explained by the fact that the range of fish ages was very low. A negative correlation of HCB with fish age has been explained by Clark \& Mackay (1991) by the possible rapid elimination due to metabolization. POP concentrations were better correlated with weight than with age, or alternatively with length. Contrary to correlations with fish age, correlations with weight or length were predominantly positive, which is in better accordance with the literature. 
Due to ability of POPs to bioaccumulate in fat tissues, POP concentrations were tested for an expected correlation with lipid content. Correlations were found for several compounds but they were significant only in one lake (ZS): g-HCH, p,p'-DDE, PCB 52, PCB 118, and PBDE 99. Gallego et al. (2007) did not find any correlation with lipid content, and Vives et al. (2005) stated that OC can be stored in all sorts of tissues, not only in fat.

Lake altitudes correlated with concentrations of a-HCH, HCB, p,p'-DDT, p,p'-DDE, PCB 28 and 52. The correlation found for a- $\mathrm{HCH}$ but not for $\mathrm{g}-\mathrm{HCH}$ is consistent with long-term effects, as the atmospheric deposition of a-HCH reflects a nearly steady state of pollution transport whereas g-HCH corresponds mostly with seasonal agricultural activities (Vives et al. 2004a). Fernández \& Grimalt (2003) concluded that bioaccumulated OC and altitude are correlated only for less-volatile compounds (DDTs and more chlorinated PCBs) but not for more-volatile compounds (HCB, less chlorinated PCBs, and HCHs). Also, Grimalt et al. (2001) and Gallego et al. (2007) found the highest concentrations of p,p'-DDT and the less volatile PCB in lakes with the highest altitudes.

POP concentrations did not differ between males and females in our study. The opposite was found by Larsson et al. (1993), Rosseland (2003), Vives et al. (2005), and Sharma et al. (2009), with the usual explanation that females lose pollutants bound to lipids during spawning. On the other hand, this hypothesis was rejected in a study by Olsson et al. (2000), done with Perca fluviatilis. Our findings should be taken with caution, however, as the number of male and female specimens and their age was different.

Correlations among g-HCH, HCB, DDTs and PCBs could indicate their similar mechanisms of transport and bioaccumulation in the Tatra Mountain lakes, and the exception of a-HCH likely reflects its different bioaccumulation behavior. Contrary to those findings, PBDEs did not show any similarity of concentration levels with other POPs and correlated only among the PBDEs congeners, thus indicating other mechanisms of deposition or bioaccumulation.

TMs were accumulated to different concentration levels in different fish tissues. The most contaminated were kidney and liver whereas the lowest concentrations were found in muscles. Interestingly, in our study the highest $\mathrm{Al}$ concentrations were found in liver and kidney, whereas $\mathrm{Al}$ is usually most accumulated in gills (Kroglund et al. 2007). Although $\mathrm{Al}$ does not usually accumulate to high concentrations as do other metals (Fe, $\mathrm{Zn}$, or $\mathrm{Cu}$ ), it can affect fish populations even in low concentrations - with impacts on growth, swimming performance, immunity or behavior (Rosseland and Staurnes 1994). Sub-lethally stressed fish can be more sensitive to illness and parasites (Iversen et al. 2005). Metal concentrations in all tissues other than gills are due to bioaccumulation, and for $\mathrm{Hg}$, due to biomagnification (Rognerud et al. 2002, Rosseland et al. 2007b). Liver and kidney have the highest concentrations of metalothionines, and therefore a high binding capacity for metals (De Smet et al. 2001).

The highest $\mathrm{TM}$ concentrations in $\mathrm{VH}$ (mainly $\mathrm{Al}, \mathrm{Cd}, \mathrm{Fe}, \mathrm{Pb}$, and $\mathrm{Ti}$ ) could be caused by the former acidification of the VH catchment supplementing this lake by metals more than MO (Kopáček et al. 2006). The other factors possibly leading to higher metal concentrations in VH could be the higher altitude, the southern exposition leading to possible higher inputs from Slovak industrial sources, the absence of vegetation accumulating metals in their bodies, and the more acidic bedrock in VH compared to MO. The only exception was $\mathrm{Zn}$ with higher concentrations in MO than in VH. One possible explanation could be the higher growth rate 
of brown trout in $\mathrm{MO}$, thus consuming higher amounts of phytoplankton and zooplankton. According to Andrzejewski (1990), Zn can be up to 30 times more accumulated in phytoplankton and zooplankton than in water. Contrary to our findings, Lysak (1996b) found higher average Zn concentrations in brown trout in the Slovak Tatras than in the Polish Tatras.

Comparing TM concentrations measured in this study with other European high-mountain lakes within the EMERGE project, it seems that VH is one of the most TMs contaminated lakes, with the highest As and Se concentrations in kidney, and comparable high concentrations of $\mathrm{Pb}$ and $\mathrm{Cd}$ as in Lochnagar in Scotland (Rosseland et al. 2007a). The enhanced export of some TMs (Al, Fe, and possibly Zn) from soils to the lakes could be explained by the relatively higher concentrations of nitrates than are typical for alpine catchment-lake ecosystems (Kopáček et al. 2005).

Trace metal concentrations can be influenced by age or body weight. Some metals can be bound to gills only in dependence on water concentrations, whereas other metals are accumulated with time (Rosseland et al. 2007a). In our study, correlation with age was found mainly in $\mathrm{VH}$ (positive: $\mathrm{Zn}, \mathrm{Se}, \mathrm{Fe}, \mathrm{Zn}$, Ti; negative: As). The negative correlation with age could be explained by the phenomenon reported by Farag et al. (1998) that small macroinvertebrates accumulate higher amounts of metals, thus small fish consuming small macroinvertebrates can obtain higher metal inputs with their food. Negative correlations with age were even found in $\mathrm{MO}(\mathrm{Ti}, \mathrm{Mn}$, $\mathrm{Zn}, \mathrm{Se}, \mathrm{Fe}, \mathrm{Ni}, \mathrm{Cd}$ ) and positive for Mn. Surprisingly, TMs correlated only scarcely with body weight in our study but better variable predicting TM concentrations was body length.

Altogether, if compared to other European high-mountain lakes, POP concentrations in fish muscle from Tatra are comparable (HCB, PBDEs), or among the higher concentrations (HCHs, DDTs, PCBs) as well as TM concentrations.

\section{Acknowledgments}

This research was financially supported by two consecutive projects: EMERGE (EVK1-CT-1999-00032) and EURO-LIMPACS (GOCE-CT-2003-505540). We also thank the Ministry of the Environment of the Czech Republic and the Grant Agency of Czech Republic for the grant 14-09231S, which enabled the final processing of results. We also sincerely thank to Peter Bitušík, Martin Blažo, Martin Černý, Barend L. van Drooge, Václav Fomín, Radek Šanda, Ingrid Vives, and Jasna Vukić for their assistance in field work and to Marie Hynštová for creating the GIS map.

\section{References}

Andrzejewski R. 1990. Drogi przemieszczania siẹ zanieczyszeń w krajobrazie, synteza. Politechnika Lubelska, Lublin, 118 pp.

Bartrons M., Grimalt J.O. \& Catalan J. 2011. Altitudinal distributions of BDE-209 and other polybromodiphenyl ethers in high mountain lakes. Environ. Pollut.159 (7): 1816-1822.

Berdie L. \& Grimalt J.O. 1998. Assessment of the sample handling procedures of a man power minimized method for the analysis of organochlorine compounds in large numbers of fish sampling. J. Chromatogr. A 823: 373-380. 
Blais J.M., Charpentié S., Pick F., Kimpe L.E., Amand A.St. \& Regnault-Roger C. 2006. Mercury, polybrominated diphenyl ether, organochlorine pesticide, and polychlorinated biphenyl concentrations in fish from lakes along and elevation transect in the French Pyrénées. Ecotoxicol. Environ. Saf. 63: 91-99.

Campbell R.N. 1979. Ferox trout, Salmo trutta L., and chair Salvelinus alpinus (L.) in Scottish lochs. J. Fish Biol. 14: 1-29.

Christensen J.H., Glasius M., Pécseli M., Platz J. \& Pritzl G. 2002. Polybrominated diphenyl ethers (PBDEs) in marine fish and blue mussels from southern Greenland. Chemosphere 47 (6): 631-638.

van Drooge B.L., Grimalt J.O. \& Stuchlík E. 2013. Spatial distribution of polychlorinated biphenyls in High Tatras lake sediments. Environ. Sci. Pollut. Res. 20 (9): 6594-6600.

Evenset A, Christensen G.N. \& Kallenborn R. 2005. Selected chloroboronanes, polychlorinated naphthalenes and brominated flame retardants in Bjørnøya (Bear Island) freshwater biota. Environ. Pollut. 136 (3): 419-430.

Farag A.M., Boese C.J., Woodward D.F. \& Bergman H.L. 1994. Physiological changes and tissue metal accumulation in rainbow trout exposed to foodborne and waterborne metals. Environ. Toxicol. Chem. 13 (12). 2021-2029.

Fernández P. \& Grimalt J.O. 2003. On the global distribution of persistent organic pollutants. Chimia 57 (9): $514-521$.

Fernández P., Carrera G. \& Grimalt J.O. 2005. Persistent organic pollutants in remote freshwater ecosystems. Aquat. Sci. 67: 263-273.

Garcia-Reyero N., Grimalt J.O., Vives I., Fernández P. \& Piňa B. 2007. Estrogenic activity associated with organochlorine compounds in fish extracts from European mountain lakes. Environ. Pollut. 145 (3): 745-752.

Grimalt J.O., Fernandez P., Berdie L., Vilanova R.M., Catalan J., Psenner R., Hofer R., Apoleny P.G., Rosseland B.O., Lien L, Massabuau J.Ch. \& Battarbee R.W. 2001 Selective trapping of organochlorine compounds in mountain lakes of temperate areas. Environ. Sci. Technol. 35 (13): 2690-2697.

Gallego E., Grimalt J.O., Bartrons M., Lopez J.F., Camarero L., Catalan J., Stuchlik E. \& Battarbee R. 2007. Altitudinal gradients of PBDEs and PCBs in fish from European high mountain lakes. Environ. Sci. Technol. 41 (7): 2196-2202.

Hammer J. 2000. Cannibals and parasites: conflicting regulators of bimodality in high latitude Arctic char, Salvelinus alpinus. Oikos 88 (1): 33-47.

Hovind H., 2005. Intercomparison 0519: pH, Cond, HCO3, NO3+NO2, Cl, SO4, Ca, Mg, Na, K, Fe, Mn, Cd, $\mathrm{Pb}, \mathrm{Cu}, \mathrm{Ni}$ and Zn. NIVA-report SNO 5068-2005, ICP Waters report 82/2005.

Hovind H. 2006. Intercomparison 0620: pH, Cond, $\mathrm{HCO} 3$, NO3+NO2, Cl, SO4, Ca, Mg, Na, K, Fe, Mn, Cd, Pb, $\mathrm{Cu}, \mathrm{Ni}$ and Zn. NIVA-report SNO 5068-2005, ICP Waters report 86/2006.

Hovind H. 2007. Intercomparison 0721: pH, Cond, HCO3, NO3-N, C1, SO4, Ca, Mg, Na, K, Fe, Mn, Cd, Pb, $\mathrm{Cu}$, Ni, and Zn. UN ICP Waters report 90/2007. Norwegian Institute for Water Research - Report 5486, http://hdl.handle.net/11250/213810. 
Ikonomou M.G., Rayner S. \& Addison R.F. 2002. Exponential increases of the brominated flame retardants, polybrominated diphenyl ethers, in the Canadian Arctic from 1981 to 2000. Environ. Sci. Technol. 36 (9): 18861892.

Iversen M., Finstad B., McKinley R.S., Eliassen R.A., Carlsen K.T. \& Evjen T. 2005. Stress responses in Atlantic salmon (Salmo salar L.) smolts during commercial well boat transports, and effects on survival after transfer to sea. Aquaculture 243 (1-4): 373-382.

Jensen H., Kiljunen M. \& Amundsen P.-A. 2012. Dietary ontogeny and niche shift to piscivory in lacustrine brown trout Salmo trutta revealed by stomach content and stable isotope analyses. J. Fish Biol. 80 (7): 24482462.

Kidd K.A., Hesslein R.H., Ross B.J., Koczanski K., Stephens G.R. \& Muir D.C.G. 1998. Bioaccumulation of organochlorines through a remote freshwater food web in the Canadian Arctic. Environ. Pollut. 102 (1): 91-103.

Kierkegaard A., Bignert A., Sellström U., Olsson M., Asplund L., Jansson B. \& de Wit C.A. 2004. Polybrominated dipheyl ethers (PBDEs) and their methoxylated derivates in pike from Swedish waters with emphasis on temporal trends, 1967-2000. Environ. Pollut. 130 (2): 187-198.

Kirka A. 1974. Populácia pstruha potočného (Salmo trutta morpha fario L.) v riečke Jelešni. Biologické práce. Vydavatelstvo slovenskej Akadémie vied, Bratislava, 53pp.

Kopáček J., Stuchlík E. \& Wright R.F. 2005. Long-term trends and spatial variability in nitrate leaching from alpine catchment-lake ecosystems in the Tatra Mountains (Slovakia-Poland). Environ. Pollut. 136 (1): 89-101.

Kopáček J., Stuchlík E. \& Hardekopf D. 2006. Chemical composition of the Tatra Mountain lakes: Recovery from acidification. Biologia 61 (Suppl. 18): 21-33.

Kroglund F., Finstad B., Stefansson S.O., Nilsen T.O., Kristensen T., Rosseland B.O., Teien H.C. \& Salbu B. 2007. Exposure to moderate acid water and aluminum reduces Atlantic salmon post-smolt survival. Aquaculture 273: $360-373$.

Larsson P., Okla L. \& and Collvin L. 1993. Reproductive status and lipid content as factors in PCB, DDT and HCH contamination of a population of pike (Esox lucius L.). Environ. Toxicol. Chem. 12 (5): 855-861.

Ligaszewski M. 1997. Charakterystyka biologiczna pstragów pobranych do označte zawartości metali cieźkich w latach 1994 - 1996. Materialy z Konferencji. Kraków, 13-16.

Luross J.M., Alaee M., Sergeant D.B., Cannon C.M., Whittle D.M., Solomon K.R. \& Muir, D.C.G. 2002. Spatial distribution of polybrominated diphenyl ethers and polybrominated biphenyls in lake trout from the Laurentian Great Lakes. Chemosphere 46 (5): 665-672.

Lysak A., Ligaszewski M. \& Mach - Paluszkiewicz Z. 1996a. Wzrost pstragów Tatra na tle indych stanowisk wysokogórskich rodziny lososiowatych. Przyroda Tatra Parku Narodowego a Czlowiek. Tom 2. Biologia. Kraków - Zakopane, 100-104.

Lysak A., Mach - Paluszkiewicz Z., Ligaszewski M. \& Surówka K. 1996b. Poziom metali ciezkich w tkankach pstragów Tatra w latach 1990 - 1994. Przyroda Tatra Parku Narodowego a Czlowiek. Tom 2. Biologia. Kraków - Zakopane: 105-107. 
Manchester-Neesving J.B., Valters K. \& Sonzogni W.C. 2001. Comparison of polybrominated diphenyl ethers (PBDEs) and polychlorinated biphenyls (PCBs) in Lake Michigan salmonids. Environ. Sci. Technol. 35 (6): 1072-1077.

McKeown N.J., Hynes R.A., Duguid R.A., Ferguson A. \& Prodoehl P.A. 2010. Phylogeographic structure of brown trout Salmo trutta in Britain and Ireland: glacial refugia, postglacial colonization and origins of sympatric populations. J. Fish Biol. 76 (2): 319-347.

Olsson A., Valters K. \& Burreau S. 2000. Concentrations of Organochlorine Substances in Relation to Fish Size and Trophic Position: A Study on Perch (Perca fluviatilis L.). Environ. Sci. Technol. 34 (23): 4878-4886.

Quirós L., Jarque S., Lackner R., Fernandez P., Grimalt J.O. \& Pina B. 2007. Physiological Response to Persistent Organic Pollutants in Fish from Mountain Lakes: Analysis of Cyp1A Gene Expression in Natural Populations of Salmo trutta. Environ. Sci. Technol. 41 (14): 5154-5160.

Rognerud S., Grimalt J.O., Rosseland B.O., Fernández P., Hofer R., Lackner R., Lauritzen B., Lien L., Massabuau J.C. \& Ribes A. 2002. Mercury and organochlorine contamination in brown trout (Salmo trutta) and arctic charr (Salvelinus alpinus) from high mountain lakes in europe and the Svalbard Archipelago. Water, Air, Soil Pollut. Focus 2 (2): 209-232.

Rosseland B.O. \& Staurnes M. 1994. Physiological mechanisms for toxic effects and resistance to acidic water: an ecophysiological and ecotoxicological approach, p. 227-246. In: Steinberg, C.E.W. \& Wright, R.F. (eds.), Acidification of Freshwater Ecosystems: Implications for the Future. John Wiley \& Sons Ltd., 420pp.

Rosseland B.O., Massabuau J.-C., Grimalt J., Hofer R., Lackner R., Raddum G., Rognerud S. \& Vives I. 2001. Fish ecotoxicology, The EMERGE Fish Sampling Manual for Live Fish, The EMERGE Project (European Mountain lake Ecosystems: Regionalisation, diaGnostic \& socio-economic valuation), http://www.mountainlakes.org/methods/index.html.

Rosseland B.O., Rognerud S., Collen P., Grimalt J.O., Vives I., Massabuau J.-C., Lackner R., Hofer R., Raddum G.G., Fjellheim A., Harriman R. \& Piña B. 2007a. Brown trout in Lochnagar: Population and contamination by metals and organic micropollutants, p. 253-285. Rose N.L (ed.), Lochnagar: The natural History of a Mountain Lake. Dev. Paleoenviron. Res. 12. Springer, 503 pp. ISBN 978-1-4020-3986-7

Sharma M.Ch., Rosseland B.O., Almvik M. \& Eklo O.M. 2009. Bioaccumulation of organochlorine pollutants in the fish community in Lake Aarungen, Norway. Environ. Pollut. 157 (8-9): 1-7.

Sjödin A., Jakobsson E., Kierkegaard A., Marsh G. \& Sellström U. 1998. Gas chromatographic identification and quantification of polybrominated diphenyl ethers in a commercial product, Bromkal 70-5DE. J. Chromatogr. A 822 (1): 83-89.

de Smet H., de Wachter B., Lobinski R. \& Blust R. 2001. Dynamics of (Cd,Zn)-metallothioneins in gills, liver and kidney of common carp Cyprinus carpio during cadmium exposure. Aquat. Toxicol. 52 (3-4): 269-281.

Villa S. Bizzotto E.C. \& Vighi M. 2011. Persistent organic pollutant in a fish community of a sub-alpine lake. Environ. Pollut.159 (4): 932-939. 
Vives I., Grimalt J.O., Catalan J., Rosseland B.O. \& Battarbee R.W. 2004a. Influence of altitude and age in the accumulation of organochlorine compounds in fish from high mountain lakes. Environ. Sci. Technol. 38 (3): 690-698.

Vives I., Grimalt J.O., Fernandez P. \& Rosseland B.O. 2004b. Polycyclic aromatic hydrocarbons in fish from remote and high mountain lakes in Europe and Greenland. Sci. Tot. Environ. 324 (1-3): 67-77.

Vives I., Grimalt J.O., Lacorte S., Guillamón M., Barceló D., Rosseland B.O. 2004c. Polybromodipheyl ether flame retardants in fish from lakes in European high mountains and Greenland. Environ. Sci. Technol. 38: 23382344

Vives I., Grimalt J.O., Ventura M., Catalan J. \& Rosseland B.O. 2005. Age dependance of the accumulation of organochlorine pollutants in brown trout (Salmo trutta) from a remote high mountain lake (Redó, Pyrenees). Environ. Pollut. 133 (2): 343-350.

de Voogt P. \& Brinkman U.A.T. 1989. Production, properties and usage of polychlorinated biphenyls, pp. 3-45. In: Kimbrough, K.D. \& Jensen A.A. (eds.), Halogenated Biphenyls, Terphenyls, Naphthalenes, Dibenzodioxins and Related Products. Elsevier Science Publishers, Amsterdam, 406pp. ISBN: 978-0-444-81029-8

Yang R., Wang Y., Li A., Zhang Q., Jing C., Wang T., Wang P., Li Y. \& Jiang G. 2010. Organochlorine pesticides and PCBs in fish from lakes of the Tibetan Plateau and the implications. Environ. Pollut. 158 (6): 2310-2316.

Wania F. \& Mackay D. 1995. A global distribution model for persistent organic chemicals. Sci. Tot. Environ.160/161: 211-232.

de Wit C.A., Alaee M. \& Muir D.C.G. 2006).Levels and trends of brominated flame retardants in the Arctic. Chemosphere 64 (2): 209-233.

Zennegg M., Kohler M., Gerecke A.C. \& Schmid P. 2003. Polybrominated diphenyl ethers in whitefish from Swiss lakes and farmed rainbow trout. Chemospere 51 (7): 545-553. 
Table 1. Characteristics of the studied lakes.

\begin{tabular}{|c|c|c|c|c|c|c|}
\hline & & Morskie Oko & Popradské pleso & Zielony Staw Gąsienicowy & Czarny Staw Polski & Vel'ké Hincovo pleso \\
\hline Altitude & $\mathrm{m}$ & 1395 & 1494 & 1672 & 1722 & 1946 \\
\hline Lake area & ha & 35.0 & 6.3 & 3.8 & 12.7 & 18.2 \\
\hline Catchment area & ha & 630 & 451 & 33 & 57 & 127 \\
\hline Orientation & & $\mathrm{NE}$ & $\mathrm{S}$ & $\mathrm{N}$ & $\mathrm{E}$ & SE \\
\hline Depth aver. & $\mathrm{m}$ & 28.4 & 8.1 & 6.8 & 22.3 & 22.7 \\
\hline Depth max. & $\mathrm{m}$ & 50.8 & 16.6 & 15.1 & 50.4 & 53.2 \\
\hline Volume & $\mathrm{m}^{3}$ & 9935000 & 504380 & 260500 & 2825800 & 4138698 \\
\hline Ice cover & days & 189 & 190 & 185 & 189 & 204 \\
\hline Fish species & & Salmo trutta & Salmo trutta & Salvelinus fontinalis & Salvelinus fontinalis & Salmo trutta \\
\hline
\end{tabular}

Table 2. Reproduction stage of females (categories after Rosseland et al. 2001).

\begin{tabular}{cl}
\hline Stage & Explanation \\
\hline I-II & fish will not spawn this year \\
III-IV & fish will spawn this year but it is still early in the season (June-August) \\
V-VI & fish is very close to spawning and eggs are becoming loose into the gut \\
VII/II & fish has already spawned and often residual eggs or "egg ghosts" (perivitelin membranes) are present in the gut \\
\hline
\end{tabular}

Table 3. Overview of sampling dates and average parameters of fish populations. Mean \pm std. deviation.

\begin{tabular}{|c|c|c|c|c|c|c|c|}
\hline Lake & $\begin{array}{c}\text { Sampling } \\
\text { date }\end{array}$ & Species & $\begin{array}{l}\text { Number of } \\
\text { specimens }\end{array}$ & Males/Females & $\begin{array}{c}\begin{array}{c}\text { Age } \\
\text { (years) }\end{array} \\
\end{array}$ & $\begin{array}{c}\text { Length } \\
(\mathrm{mm})\end{array}$ & $\begin{array}{c}\text { Weight } \\
(\mathrm{g})\end{array}$ \\
\hline Morskie Oko ${ }^{a}$ & 23.8 .2004 & Salmo trutta & 14 & $10 / 4$ & $7.1 \pm 3.4$ & $207 \pm 98$ & $229 \pm 603$ \\
\hline Morskie Oko ${ }^{b} *$ & 11.10 .2004 & Salmo trutta & 5 & $2 / 3$ & $8.2 \pm 1.2$ & $212 \pm 29$ & $97 \pm 46$ \\
\hline Popradské pleso & 22.8 .2004 & Salmo trutta & 14 & $11 / 3$ & $7.2 \pm 2.3$ & $190 \pm 27$ & $70 \pm 40$ \\
\hline Czarny Staw Polski & 24.8.2004 & Salvelinus fontinalis & 12 & $7 / 5$ & $5.1 \pm 0.8$ & $332 \pm 42$ & $436 \pm 119$ \\
\hline Vel'ké Hincovo pleso 2001 & 25.9.2001 & Salmo trutta & 20 & $12 / 8$ & $10 \pm 4$ & $210 \pm 46$ & $101 \pm 51$ \\
\hline Vel'ké Hincovo pleso 2004 & 25.8 .2004 & Salmo trutta & 14 & $12 / 2$ & $5.9 \pm 0.9$ & $164 \pm 12$ & $46 \pm 10$ \\
\hline
\end{tabular}

* fish sampled for TM analysis 
Table 4. Overview of significant $(\mathbf{p}<0.05)$ correlations of POPs concentrations with age, length, weight, condition factor, and lipid content $(r-v a l u e)$. MO=Morskie Oko, VH=Vel'ké Hincovo, $\mathrm{k}=$ kidney, l=liver, $\mathrm{g}=$ gill, $\mathbf{m}=$ =muscle.

\begin{tabular}{|c|c|c|c|c|c|}
\hline & Age & Length & Weight & Condition factor & Lipid content \\
\hline $\mathrm{a}-\mathrm{HCH}$ & MO (-0.61) & CS $(0.62)$ & CS (0.67) & & \\
\hline $\mathrm{g}-\mathrm{HCH}$ & & & & CS (0.68) & $\mathrm{ZS}(0.61)$ \\
\hline $\mathrm{HCB}$ & $\mathrm{ZS}(-0.58)$ & & VH $(0.54)$ & $\mathrm{MO}(0.65), \mathrm{PP}(0.65), \mathrm{VH}(0.58)$ & $\mathrm{PP}(0.84)$ \\
\hline $\mathrm{p}, \mathrm{p}^{\prime}-\mathrm{DDT}$ & MO (-0.60) & & $\mathrm{PP}(0.54), \mathrm{ZS}(-0.68)$ & $\mathrm{PP}(0.57)$ & $\mathrm{PP}(0.59)$ \\
\hline $\mathrm{p}, \mathrm{p}^{\prime}-\mathrm{DDE}$ & & CS $(0.61)$ & PP (0.57), CS (0.70) & $\mathrm{PP}(0.58)$ & $\mathrm{PP}(0.70), \mathrm{ZS}(0.67)$ \\
\hline PCB 28 & & & & $\mathrm{ZS}(-0.63), \mathrm{VH}(0.72)$ & \\
\hline РCB 52 & CS $(-0.63)$ & & & CS (0.75), VH (0.60) & ZS (0.67) \\
\hline PCB 101 & CS $(-0.62)$ & $\mathrm{PP}(0.62)$ & $\mathrm{PP}(0.69)$ & $\mathrm{PP}(0.58), \mathrm{CS}(0.66)$ & \\
\hline PCB 118 & & $\mathrm{PP}(0.60)$ & $\mathrm{PP}(0.65), \mathrm{CS}(0.63)$ & $\mathrm{PP}(0.61)$ & $\mathrm{PP}(0.60), \mathrm{ZS}(0.55)$ \\
\hline PCB 138 & & $\mathrm{PP}(0.56)$ & $\mathrm{PP}(0.64)$ & $\mathrm{PP}(0.56)$ & $\mathrm{PP}(0.69)$ \\
\hline \multicolumn{6}{|l|}{ PCB 153} \\
\hline \multicolumn{6}{|l|}{ PCB 180} \\
\hline PBDE 28 & & & & $\mathrm{PP}(-0.56)$ & \\
\hline PBDE 47 & & & & VH $(0.56)$ & \\
\hline PBDE 99 & & PP (0.60), CS (0.69) & $\mathrm{PP}(0.57), \mathrm{CS}(0.71)$ & & $\mathrm{ZS}(0.62)$ \\
\hline PBDE 100 & & $\mathrm{PP}(0.62)$ & CS $(0.61)$ & & \\
\hline PBDE 153 & MO (0.56) & $\mathrm{PP}(0.59)$ & & & \\
\hline PBDE 154 & & $\mathrm{PP}(0.60)$ & & & \\
\hline
\end{tabular}


Table 5. Metal concentrations in different fish tissues $\left(\mathrm{mg} \mathrm{kg}^{-1} \mathrm{dw}\right)$. Mean \pm std. deviation.

\begin{tabular}{ccccccccccccc}
\hline Site & Tissue & $\mathbf{A s}$ & $\mathbf{A l}$ & $\mathbf{C d}$ & $\mathbf{C u}$ & $\mathbf{F e}$ & $\mathbf{M n}$ & $\mathbf{N i}$ & $\mathbf{P b}$ & $\mathbf{S e}$ & $\mathbf{T i}$ & $\mathbf{Z n}$ \\
\hline \multirow{2}{*}{ Morskie Oko } & kidney & $0.56 \pm 0.42$ & $8.6 \pm 2.2$ & $9.5 \pm 3.4$ & $12 \pm 2$ & $747 \pm 249$ & $2.0 \pm 0.5$ & $0.27 \pm 0.11$ & $1.4 \pm 0.9$ & $9.6 \pm 3.7$ & $0.92 \pm 0.08$ & $177 \pm 30$ \\
& liver & $0.12 \pm 0.10$ & $4.3 \pm 1.1$ & $2.3 \pm 1.4$ & $457 \pm 302$ & $464 \pm 171$ & $2.8 \pm 0.4$ & $0.11 \pm 0.04$ & $0.16 \pm 0.04$ & $37 \pm 30$ & $0.65 \pm 0.08$ & $201 \pm 34$ \\
& gill & $0.08 \pm 0.07$ & $2.3 \pm 1.9$ & $0.80 \pm 0.40$ & $2.9 \pm 1.3$ & $133 \pm 29$ & $7.9 \pm 1.7$ & $0.23 \pm 0.10$ & $1.3 \pm 0.9$ & $1.7 \pm 0.8$ & $0.78 \pm 0.12$ & $159 \pm 58$ \\
& muscle & $0.31 \pm 0.34$ & $0.0 \pm 0.0$ & $0.02 \pm 0.02$ & $1.3 \pm 0.5$ & $23 \pm 6$ & $0.50 \pm 0.06$ & $0.05 \pm 0.01$ & $0.18 \pm 0.30$ & $2.2 \pm 1.1$ & $0.61 \pm 0.08$ & $27 \pm 8$ \\
Velkké Hincovo & kidney & $2.1 \pm 1.7$ & $53 \pm 44$ & $63 \pm 22$ & $13 \pm 3$ & $1942 \pm 710$ & $2.6 \pm 1.0$ & $0.74 \pm 0.75$ & $16 \pm 9$ & $47 \pm 15$ & $1.2 \pm 0.2$ & $167 \pm 40$ \\
& liver & $0.27 \pm 0.18$ & $70 \pm 79$ & $10 \pm 8$ & $907 \pm 369$ & $1152 \pm 656$ & $4.5 \pm 1.5$ & $0.13 \pm 0.03$ & $0.87 \pm 0.61$ & $144 \pm 66$ & $0.77 \pm 0.10$ & $113 \pm 11$ \\
& gill & $0.15 \pm 0.06$ & $22 \pm 18$ & 3.03 & $1.5 \pm 0.4$ & $166 \pm 44$ & $18 \pm 19$ & $0.37 \pm 0.27$ & $6.1 \pm 4.9$ & $6.0 \pm 1.7$ & $1.1 \pm 0.3$ & $133 \pm 31$ \\
& muscle & $0.13 \pm 0.04$ & $2.7 \pm 1.2$ & $0.07 \pm 0.05$ & $1.8 \pm 0.5$ & $55 \pm 22$ & $0.63 \pm 0.11$ & $0.07 \pm 0.03$ & $0.10 \pm 0.05$ & $7.4 \pm 1.5$ & $0.72 \pm 0.06$ & $30 \pm 7$ \\
\hline
\end{tabular}

Table 6. Overview of significant $(\mathbf{p}<0.05)$ correlations of metal concentrations with age, length, weight, and condition factor. MO=Morskie Oko, VH=Vel'ké Hincovo, $k=k i d n e y, ~ l=l i v e r, ~ g=$ gill, $m=$ muscle, - negative correlation.

\begin{tabular}{|c|c|c|c|c|c|c|c|c|c|c|c|}
\hline & Al & As & Cd & $\mathbf{C u}$ & Fe & Mn & $\mathbf{N i}$ & $\mathbf{P b}$ & Se & $\mathbf{T i}$ & Zn \\
\hline Age & VH_m & VH_g- & VH_k & $\begin{array}{l}\text { MO_g } \\
\text { VH_m }\end{array}$ & $\begin{array}{l}\text { VH_k } \\
\text { VH_m }\end{array}$ & & $\begin{array}{l}\text { VH_k- } \\
\text { VH_g- }\end{array}$ & & $\begin{array}{l}\text { VH_k } \\
\text { VH_1 }\end{array}$ & $\begin{array}{l}\text { VH_k } \\
\text { VH_g }\end{array}$ & VH_m \\
\hline Length & $\begin{array}{l}\text { VH_g } \\
\text { VH_m }\end{array}$ & & VH_k & MO_k & $\begin{array}{l}\text { VH_k } \\
\text { VH_l } \\
\text { VH_m }\end{array}$ & $\begin{array}{l}\text { MO_g- } \\
\text { MO_l- }\end{array}$ & VH_g- & VH_k & VH_k & $\begin{array}{c}\text { VH_k } \\
\text { VH_g } \\
\text { MO_m }\end{array}$ & MO_k \\
\hline Weight & & & & & & & & MO_k- & & $\begin{array}{c}\text { VH_k } \\
\text { MO_g- }\end{array}$ & MO_1- \\
\hline Condition factor & VH_m- & MO_1- & $\begin{array}{l}\text { VH_k- } \\
\text { VH_m- }\end{array}$ & & $\begin{array}{l}\text { VH_k- } \\
\text { VH_m- }\end{array}$ & & $\begin{array}{l}\text { VH_k } \\
\text { VH_g }\end{array}$ & & $\begin{array}{l}\text { VH_k- } \\
\mathrm{MO}_{-} \mathrm{k}- \\
\mathrm{MO} \_1-\end{array}$ & $\begin{array}{l}\text { VH_k- } \\
\text { VH_g- } \\
\text { VH_m- }\end{array}$ & \\
\hline
\end{tabular}




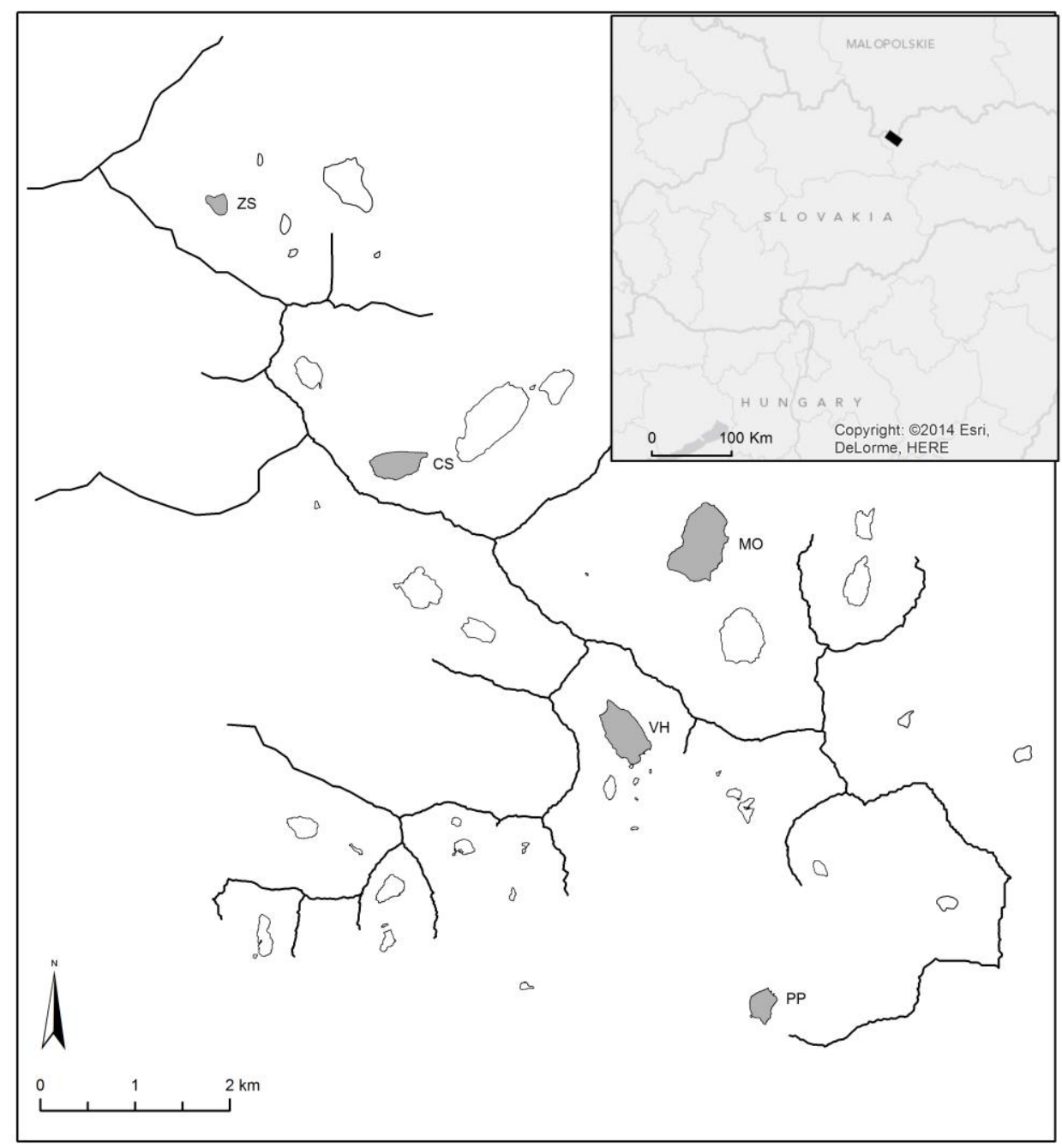

Fig. 1. Map of the sampled lakes (grey fill), both in Slovakia and Poland. Lines indicate the main mountain ridges. $\mathrm{MO}=$ Morskie Oko, $\mathrm{PP}=$ Popradské pleso, $\mathrm{ZS}=$ Zielony Staw Gąsienicowy, $\mathrm{CS}=\mathrm{Czarny}$ Staw Polski, VH=Vel'ké Hincovo pleso 


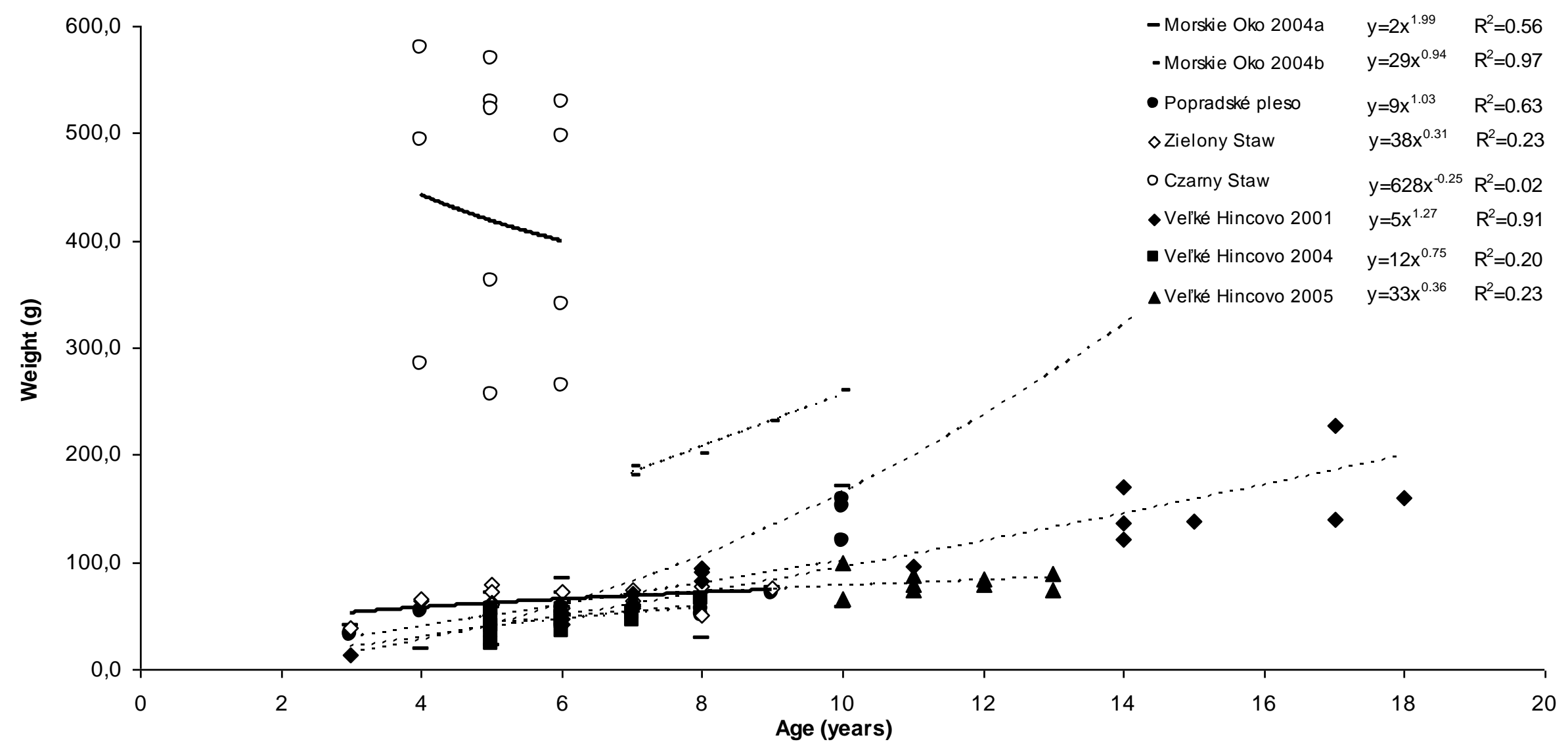

Fig. 2. Age-weight relationships. Filled symbols and dotted lines for brown trout (Salmo trutta), empty symbols and solid lines for brook trout (Salvelinus fontinalis). The heaviest specimen from MO is outside of the graph. 


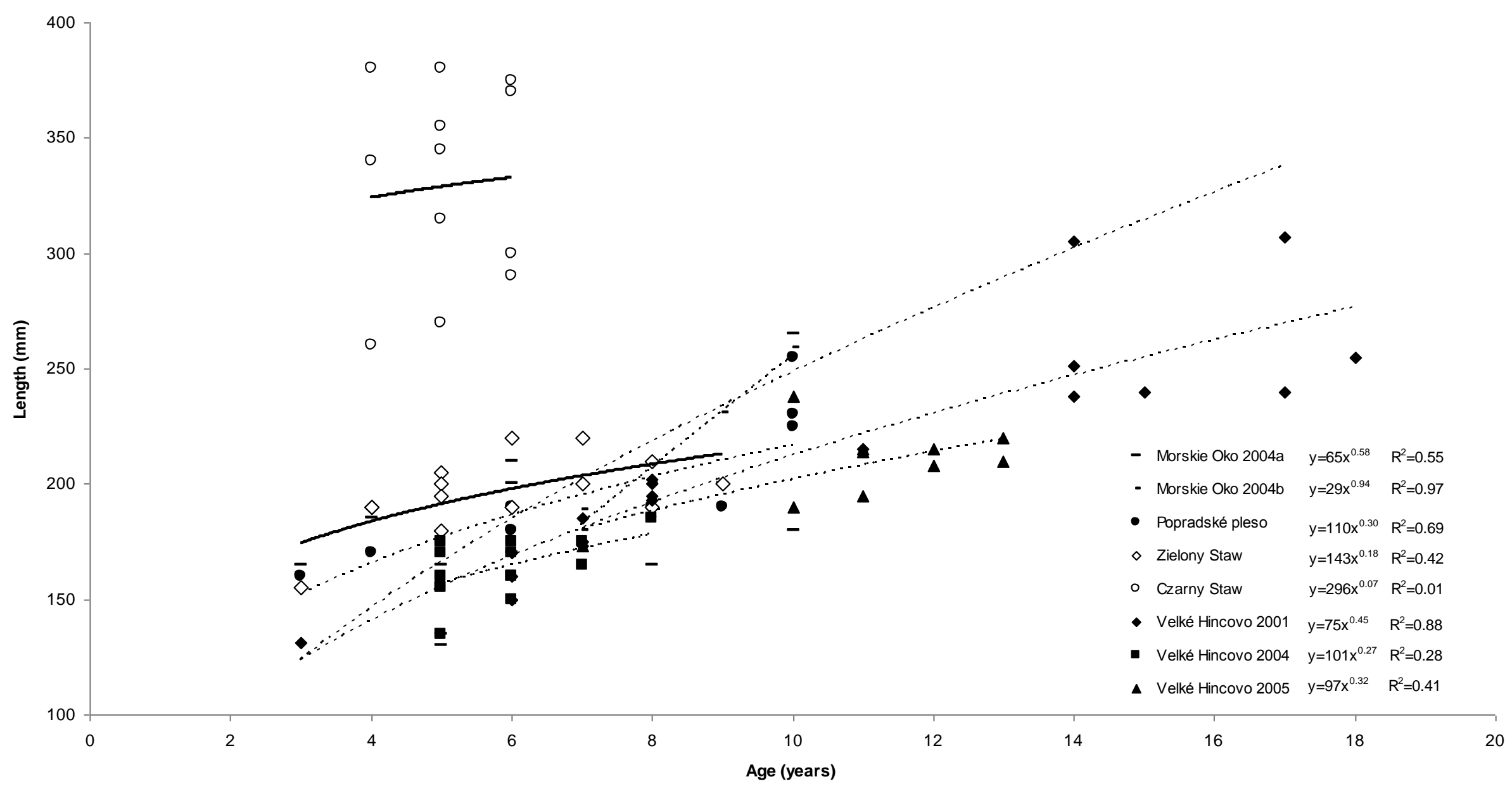

Fig. 3. Age-length relationships. Filled symbols and dotted lines for brown trout (Salmo trutta), empty symbols and solid lines for brook trout (Salvelinus fontinalis). The longest specimen from MO is outside of the graph. 

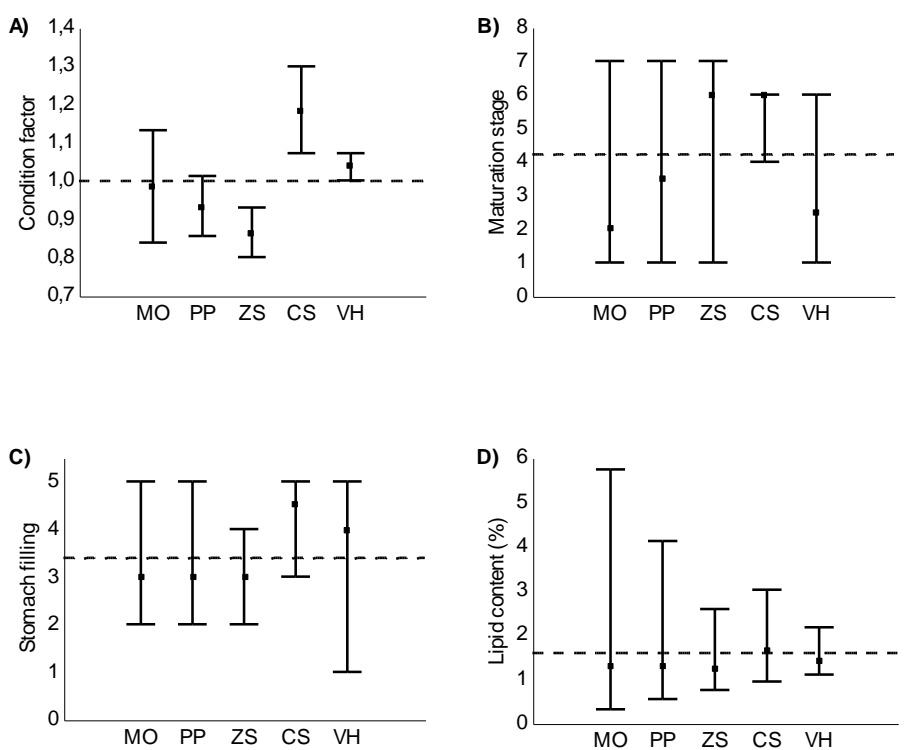

Fig. 4. Fish characteristics.

Median, - Min-Max, dashed line represents a mean value.

0

1

2

4

5

6

7

8

9

10

11

12 


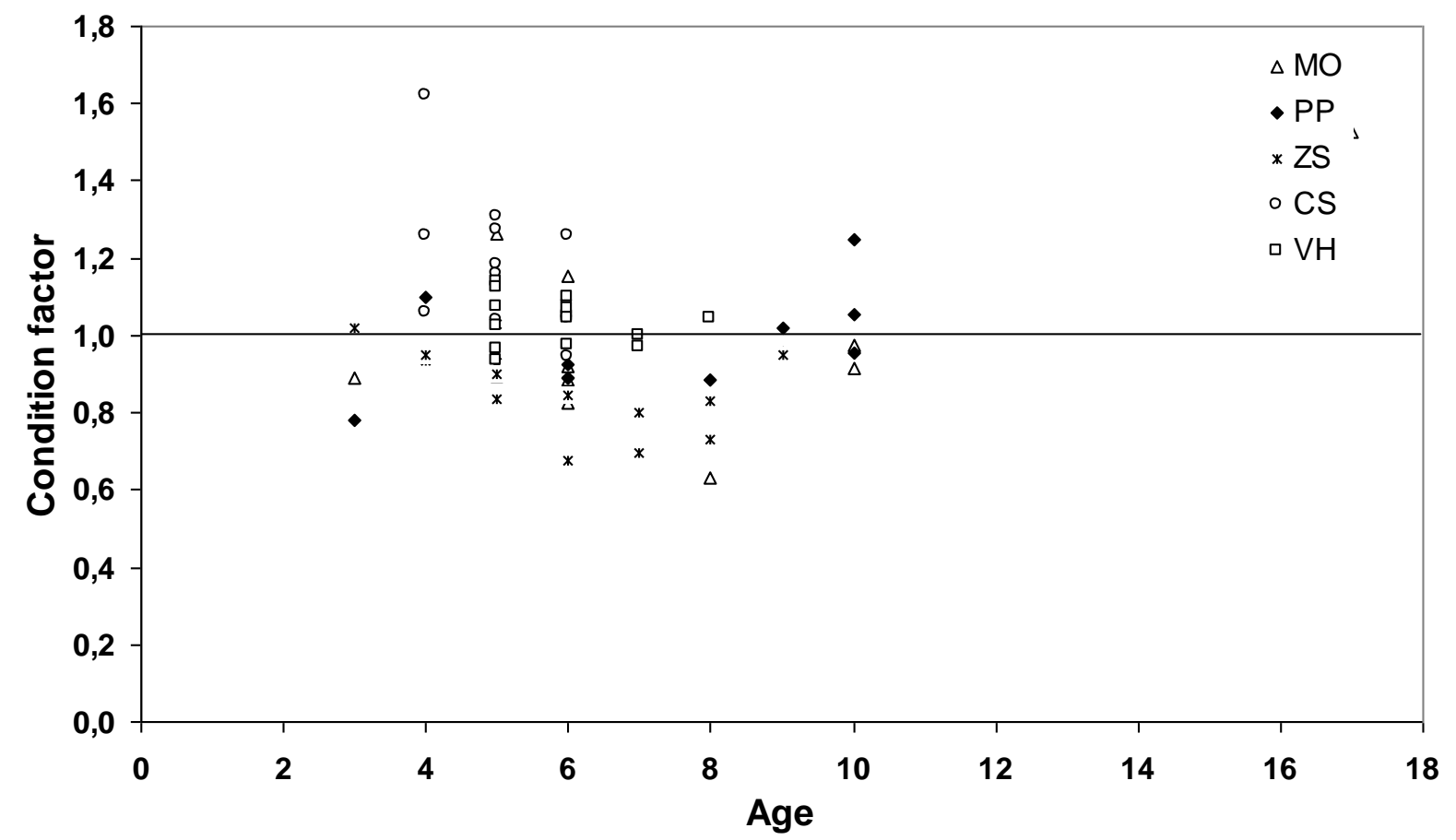

13

14 Fig. 5. Condition factor vs. age for both fish species in five lakes sampled in 2004. Line represents a mean 15 value.

16 

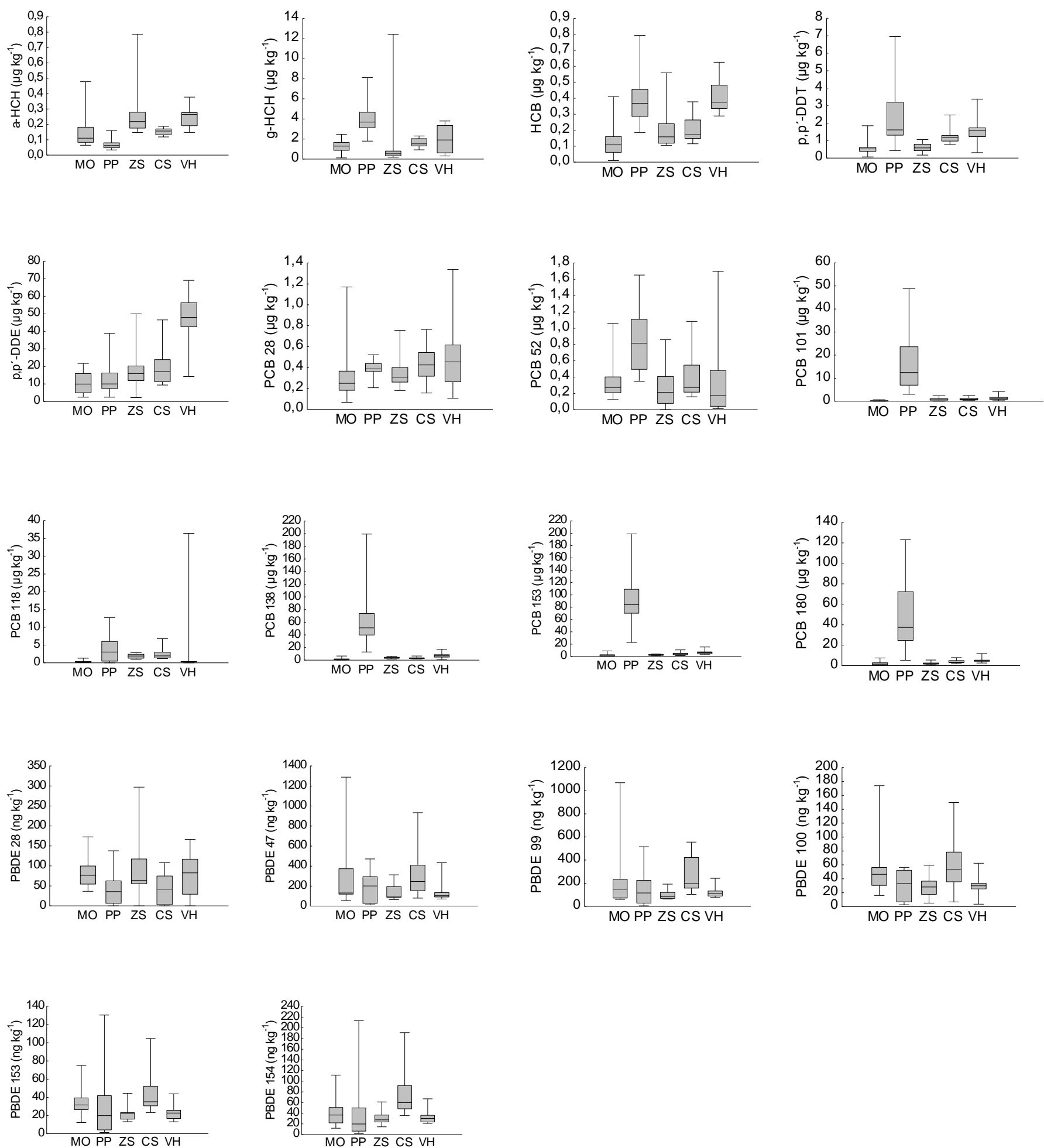

Median, $\square$ 25\%-75\%, - Min-Max. The outlier from MO not shown. 


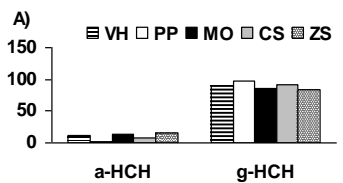

21
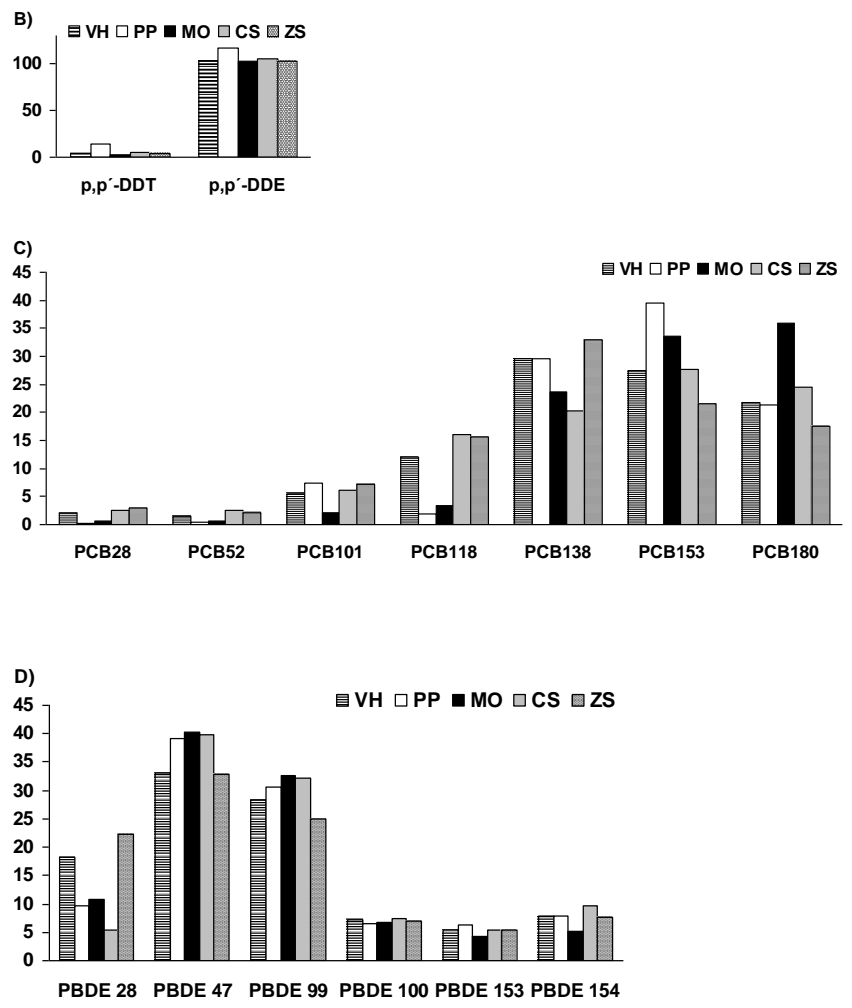

Fig. 7. Relative proportions of A) HCH isomers to the sum of HCHs (\%), B) DDTs to the sum of DDTs 26 (\%), C) particular congeners to the sum of PCBs (\%), and D) particular congeners to the sum of PBDEs $27(\%)$. 